\title{
MAGISTRALNO IN REGIONALNO CESTNO OMREŽJE IN OBČINSKA SREDIŠČA V SLOVENIJI
}

\author{
Andrej Černe*
}

Izvleček

UDK 911·375:656.1 (497.12)

Predstavljeni so prvi delni rezultati prometno-geografske analize 56. nekdanjih občinskih središč v Sloveniji. Analizirano je cestno omrežje z namenom, da bi spoznali njegov pomen za nodalnost nekdanjih občinskih središč.

Ključne besede: cestno omrežje, občinsko središče, Slovenija

\section{MAIN AND REGIONAL ROAD NETWORK AND MUNICIPAL \\ CENTERS IN SLOVENIA}

Abstract

UDC $911 \cdot 375: 656.1$ (497.12)

The first partial results of the transport-geographical analysis are presented, of the former 56 municipal centers in Slovenia. The road network has been analysed with the purpose of establishing its significance for the nodality of former municipal centers.

Key words: Road network, Municipal centers, Slovenia

\section{NODALNOST}

Urbani teoretiki trde, da obstajata dva učinkovita načina prometnega povezovanja urbanih središč, ki sta ju v obliki modela predstavila Christaller in Lösch. V obeh primerih gre za poudarjanje "šesterokotnega načela". Christaller je opredelil šesterokotni način povezovanja centralnih naselij, Lösch pa je predpostavljal, da je nodalnost opredeljena $\mathrm{z}$ dvanajstimi prometnicami. Obe teoriji sta zasnovani na predpostavki, da v dolgoročnem smislu teži razporeditev centralnih naselij k optimalnemu prostorskemu ravnotežju. Razporeditev centralnih naselij naj bi imela obliko šesterokotnega omrežja, znotraj katerega so naselja razporejena $v$ razmeroma enakomerni oddaljenosti drug od drugega. Christaller je zagovarjal šesterokotno hierarhijo centralnih naselij, ki je sestavljena iz šestih radialnih povezav, ki so usmerjene k najbližjim centralnim naseljem. Lösch pa je predpostavljal kvadratno strukturo hiererhije centralnih naselij. Trdil je, da je pravokotni sistem idealna organizacija prostora za vse tiste pokrajine, ki so imele "grid" za zasnovo poselitve (Lösch, 1954).

\footnotetext{
* Dr., izr. prof., Oddelek za geografijo, Filozofska fakulteta Univerze v Ljubljani, Aškerčeva 2, 61000 Ljubljana, Slovenija
} 


\section{PROMETNO OMREŽJE IN OBČINSKA SREDIŠČA}

Pri analizi prometnega omrežja občinskih središč smo upoštevali 56 nekdanjih občinskih središč in njihov položaj v razmerju do poteka magistralnih in regionalnih cest in sicer tistih, ki vodijo neposredno $v$ oziroma iz občinskih središč. Za osnovno analitično podlago smo uporabili Atlas Slovenije s topografskimi kartami v merilu $1: 50.000$. Za vsako občinsko središče smo določili radij $2 \mathrm{~km}$ in znotraj tega vse magistralne in regionalne ceste, ki vodijo $\mathrm{v}$ in iz občinskih središč. Pri določanju kategorije cest smo uporabljali kategorizacijo cest Republiške uprave za ceste. Na ta način smo analizirali 243 magistralnih in regionalnih cest, in sicer 107 magistralnih in 136 regionalnih. To pomeni, da vodijo $v$ oziroma iz vsakega občinskega središča $v$ povprečju 4,3 ceste. Med vsemi občinskimi središči je največ takih, ki imajo 4 magistralne in regionalne ceste. Delež teh znaša $34,0 \%$. Občinskih središč s tremi magistralnimi cestami je $23,2 \%$, občinskih središč s petimi pa prav tako $23,2 \%$. Štiri oziroma manj kot štiri magistralne in regionalne ceste ima 35 središč ali skoraj dve tretini $(62,5 \%)$ vseh, $v$ in iz 21. središč pa vodi 5 in več magistralnih in regionalnih cest. To govori v prid kvadratni zasnovi magistralnega in regionalnega cestnega omrežja, ne pa o heksagonalni Christallerjevi teoriji o centralnih naseljih.

Občinska središča, skozi katera ne potekajo magistralne ceste: Cerknica, Črnomelj, Grosuplje, Hrastnik, Kamnik, Ljutomer, Mozirje, Ravne na Koroškem, Škofja Loka, Trbovlje, Zagorje ob Savi.

Občinska središča z 9 magistralnimi in regionalnimi cestami: Ljubljana, Ptuj.

Občinsko središče z 8 magistralnimi in regionalnimi cestami: Kranj.

Občinsko središče s 7 magistralnimi in regionalnimi cestami: Novo mesto.

Občinska središča s 6 magistralnimi in regionalnimi cestami: Brežice, Ilirska Bistrica, Maribor, Nova Gorica.

Občinska središča s 5 magistralnimi in regionalnimi cestami: Celje, Domžale, Dravograd, Kamnik, Lendava, Litija, Logatec, Murska Sobota, Radovljica, Slovenske Konjice, Trebnje, Tržič, Velenje.

Občinska središča s 4 magistralnimi in regionalnimi cestami: Črnomelj, Grosuplje, Idrija, Izola, Koper, Krško, Lenart, Metlika, Ormož, Postojna, Radlje ob Dravi, Sevnica, Sežana, Slovenska Bistrica, Šentjur pri Celju, Škofja Loka, Trbovlje, Vrhnika, Žalec.

Občinska središča s 3 magistralnimi in regionalnimi cestami: Ajdovščina, Cerknica, Gornja Radgona, Hrastnik, Jesenice, Kočevje, Ljutomer, Mozirje, Piran, Ravne na Koroškem, Slovenj Gradec, Tolmin, Zagorje ob Savi.

Občinska središča z 2 magistralnima in regionalnima cestama: Laško, Ribnica, Šmarje pri Jelšah. 
Tabela 1: Občinska središča in število magistralnih in regionalnih cest

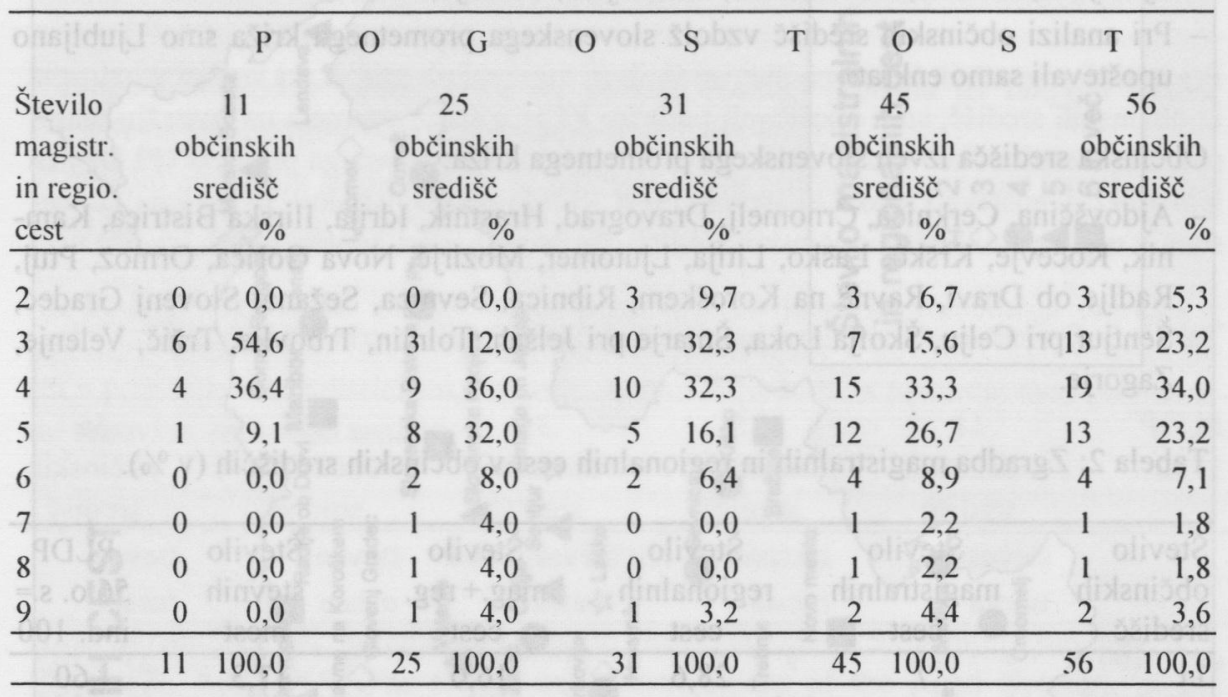

\section{PRIMERJALNA ANALIZA}

Pri primerjalni analizi prometnega omrežja občinskih središč nas je zanimala sestava magistralnih in regionalnih cest $v$ občinskih središčih, glede na njihov prometno-geografski položaj in glede na velikost središč. Prometno-geografski položaj središč smo določili na podlagi regionalnega položaja središč $v$ celotnem omrežju magistralnih in regionalnih cest, velikost središč pa s številom prebivalstva leta 1991.

Za potrebe primerjalne analize sestave cestnega omrežja občinskih središč smo središča razvrstili v naslednje skupine:

- občinska središča, skozi katera ne potekajo magistralne ceste (11);

- občinska središča, ki leže vzdolž slovenskega prometnega križa (25);

- občinska središča, ki leže izven slovenskega prometnega križa (31);

- občinska središča, skozi katera potekajo magistralne in regionalne ceste (45);

- vsa občinska središča (56).

Občinska središča vzdolž slovenskega prometnega križa:

- občinska središča vzdolž JZ-SV koridorja: Celje, Domžale, Gornja Radgona, Izola, Koper, Lenart, Lendava, Ljubljana, Logatec, Maribor, Murska Sobota, Piran, Postojna, Slovenska Bistrica, Slovenske Konjice, Vrhnika, Žalec; 
- občinska središča vzdolž SZ-JV koridorja: Brežice, Grosuplje, Jesenice, Kranj, Ljubljana, Metlika, Novo mesto, Radovljica, Trebnje;

- Pri analizi občinskih središč vzdolž slovenskega prometnega križa smo Ljubljano upoštevali samo enkrat.

Občinska središča izven slovenskega prometnega križa:

- Ajdovščina, Cerknica, Črnomelj, Dravograd, Hrastnik, Idrija, Ilirska Bistrica, Kamnik, Kočevje, Krško, Laško, Litija, Ljutomer, Mozirje, Nova Gorica, Ormož, Ptuj, Radlje ob Dravi, Ravne na Koroškem, Ribnica, Sevnica, Sežana, Slovenj Gradec, Šentjur pri Celju, Škofja Loka, Šmarje pri Jelšah, Tolmin, Trbovlje, Tržič, Velenje, Zagorje.

Tabela 2: Zgradba magistralnih in regionalnih cest $\mathrm{v}$ občinskih središčih $(\mathrm{v} \%)$.

\begin{tabular}{lccccc}
\hline $\begin{array}{l}\text { Število } \\
\text { občinskih } \\
\text { središc }\end{array}$ & $\begin{array}{c}\text { Število } \\
\text { magistralnih } \\
\text { cest }\end{array}$ & $\begin{array}{c}\text { Število } \\
\text { regionalnih } \\
\text { cest }\end{array}$ & $\begin{array}{c}\text { Število } \\
\text { mag.+ reg. } \\
\text { cest }\end{array}$ & $\begin{array}{c}\text { Število } \\
\text { stevnih } \\
\text { mest }\end{array}$ & $\begin{array}{c}\text { PLDP } \\
56 \text { o. S. } \\
\text { ind. 100 }\end{array}$ \\
\hline 11 & 1 & 28,6 & 16,0 & 17,3 & 60 \\
25 & 57,0 & 44,1 & 49,8 & 49,5 & 136 \\
31 & 42,9 & 55,8 & 50,2 & 50,4 & 64 \\
45 & 100,0 & 71,3 & 83,9 & 82,7 & 108 \\
\hline
\end{tabular}

Občinska središča, ki so navezana na slovenski prometni križ, imajo večje število magistralnih in regionalnih cest v primerjavi z ostalimi občinskimi središči. $57 \%$ vseh magistralnih in regionalnih cest, ki potekajo $\mathrm{v}$ in iz občinskih središč je navezanih na središča znotraj slovenskega prometnega križa, $43 \%$ pa na ostala središča. Pri številu regionalnih cest pa je podoba obrnjena. Glede na število vseh magistralnih in regionalnih cest pa med občinskimi središči znotraj slovensekga prometnega križa in ostalimi središči ni bistvenih razlik. Tudi ti podatki govore o razmeroma dobri medregionalni in regionalni povezanosti občinskih središč, izraženi seveda zgolj s številom magistralnih in regionalnih cest, ki vodijo $v$ oziroma iz teh središč.

Osnovne poteze razmerja med sestavo prometnega omrežja občinskih središč in njihovim številom prebivalstva bi lahko strnili v naslednji splošni ugotovitvi:

- v 21. občinskih središčih, ki imajo "heksagonalno zasnovo" magistralnega in regionalnega cestnega omrežja (občinska središča s petimi in več kot petimi magistralnimi in regionalnimi cestami) je leta 1991 živelo 608.262 prebivalcev ozoroma $72,1 \%$ vseh prebivalcev občinskih središč;

- v 35. občinskih središčih s štirimi oziroma manj kot štirimi magistralnimi in regionalnimi cestami pa je živelo leta 1991234.908 prebivalcev ali $27,9 \%$ vseh prebivalcev občinskih središč. 


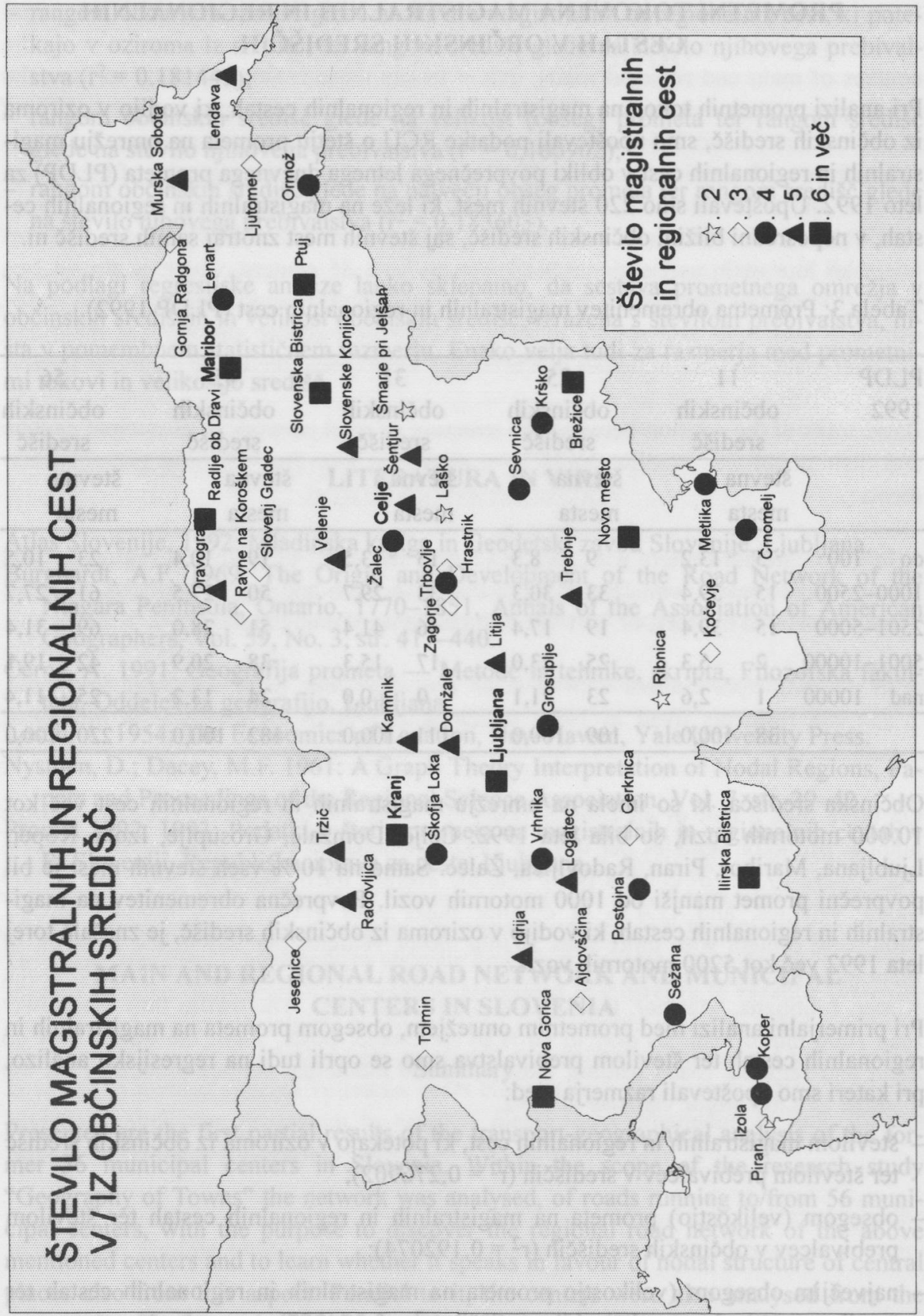




\section{PROMETNI TOKOVI NA MAGISTRALNIH IN REGIONALNIH CESTAH V OBČINSKIH SREDIŠČIH}

Pri analizi prometnih tokov na magistralnih in regionalnih cestah, ki. vodijo $v$ oziroma iz občinskih središč, smo upoštevali podatke RCU o štetju prometa na omrežju magistralnih in regionalnih cest $\mathrm{v}$ obliki povprečnega letnega dnevnega prometa (PLDP) za leto 1992. Upoštevali smo 220 števnih mest, ki leže na magistralnih in regionalnih cestah, v neposredni bližini občinskih središč, saj števnih mest znotraj samih središč ni.

Tabela 3: Prometna obremenitev magistralnih in regionalnih cest (PLDP 1992).

\begin{tabular}{|c|c|c|c|c|c|c|c|c|c|}
\hline \multirow{2}{*}{$\begin{array}{l}\text { PLDP } \\
1992 \\
\end{array}$} & \multicolumn{2}{|c|}{$\begin{array}{c}11 \\
\text { občinskih } \\
\text { središč }\end{array}$} & \multicolumn{2}{|c|}{$\begin{array}{c}25 \\
\text { občinskih } \\
\text { središč }\end{array}$} & \multicolumn{2}{|c|}{$\begin{array}{c}31 \\
\text { občinskih } \\
\text { središč }\end{array}$} & \multicolumn{2}{|c|}{$\begin{array}{c}45 \\
\text { občinskih } \\
\text { središč }\end{array}$} & $\begin{array}{c}56 \\
\text { občinskih } \\
\text { središč }\end{array}$ \\
\hline & $\begin{array}{l}\text { števn } \\
\text { mesta }\end{array}$ & & $\begin{array}{l}\text { števn } \\
\text { mest }\end{array}$ & & $\begin{array}{l}\text { števna } \\
\text { mesta }\end{array}$ & & $\begin{array}{l}\text { števna } \\
\text { mesta }\end{array}$ & & $\begin{array}{c}\text { Števna } \\
\text { mesta }\end{array}$ \\
\hline 100 & 5 & 13,2 & 9 & 8,3 & 15 & 13,5 & 19 & 10,4 & $23 \quad 10,5$ \\
\hline $1000-2500$ & 15 & 39,4 & 33 & 30,3 & 33 & 29,7 & 50 & 27,5 & $61 \quad 27,7$ \\
\hline $2501-5000$ & 15 & 39,4 & 19 & 17,4 & 46 & 41,4 & 51 & 28,0 & $69 \quad 31,4$ \\
\hline $5001-10000$ & 2 & 5,3 & 25 & 23,0 & 17 & 15,3 & 38 & 20,9 & $42 \quad 19,1$ \\
\hline had 10000 & 1 & 2,6 & 23 & 21,1 & 0 & 0,0 & 24 & 13,2 & $25 \bigcirc 11,4$ \\
\hline & 38 & 00,0 & 109 & 100,0 & 111 & 100,0 & 182 & 100,0 & $220 \quad 100,0$ \\
\hline
\end{tabular}

Občinska središča, ki so imela na omrežju magistralnih in regionalnih cest več kot 10.000 motornih vozil, so bila leta 1992: Celje, Domžale, Grosuplje, Izola, Koper, Ljubljana, Maribor, Piran, Radovljica, Žalec. Samo na 10 \% vseh števnih mest je bil povprečni promet manjši od 1000 motornih vozil. Povprečna obremenitev na magistralnih in regionalnih cestah, ki vodijo v oziroma iz občinskih središč, je znašala torej leta 1992 več kot 5200 motornih vozil.

Pri primerjalni analizi med prometnim omrežjem, obsegom prometa na magistralnih in regionalnih cestah ter številom prebivalstva smo se oprli tudi na regresijsko analizo, pri kateri smo upoštevali razmerja med:

- številom magistralnih in regionalnih cest, ki potekajo $v$ oziroma iz občinskih središč ter številom prebivalcev $v$ središčih $\left(r^{2}=0,276902\right)$;

- obsegom (velikostjo) prometa na magistralnih in regionalnih cestah ter številom prebivalcev $v$ občinskih središčih $\left(r^{2}=0,192074\right)$;

- največjim obsegom (velikostjo prometa na magistralnih in regionalnih cestah ter številom prebivalcev $v$ občinskih središčih $\left(\mathrm{r}^{2}=0,374977\right)$; 
- rangom občinskih središč glede na število magistralnih in regionalnih cest, ki potekajo v oziroma iz središč, ter rangom središč glede na število njihovega prebivalstva $\left(\mathrm{r}^{2}=0,181445\right)$;

- rangom občinskih središč glede na velikost (obseg) prometa ter rangom središč glede na število njihovega prebivalstva $\left(r^{2}=0,160902\right)$;

- rangom občinskih središč glede na največji obseg prometa ter rangom središč glede na število njhovega prebivalstva $\left(r^{2}=0,183603\right)$.

Na podlagi regresijske analize lahko sklepamo, da sestava prometnega omrežja $v$ občinskih središčih in velikost občinskih središč, izražena s številom prebivalstva, nista v pomembnem statističnem razmerju. Enako velja tudi za razmerja med prometnimi tokovi in velikostjo središč.

\section{LITERATURA IN VIRI}

Atlas Slovenije, 1992: Mladinska knjiga in Geodetski zavod Slovenije, Ljubljana.

Burghardt, A.F. 1969: The Origin and Development of the Road Network of the Niagara Peninsula, Ontario, 1770-1851, Annals of the Association of American Geographers, Vol. 59, No. 3, str. 417-440.

Černe, A. 1991: Geografija prometa - Metode in tehnike, skripta, Filozofska fakulteta, Oddelek za geografijo. Ljubljana.

Losch, A. 1954: The Economics of Location, New Hawen, Yale University Press.

Nystuen, D.; Dacey, M.F. 1961: A Graph Theory Interpretation of Nodal Regions, Papers and Proceedings of the Regional Science Association, Vol. 7, str. 29-42.

Promet 1992, 1993: Podatki o štetju prometa na magistralnih in regionalnih cestah v R. Sloveniji, Republiška uprava za ceste. Ljubljana.

\section{MAIN AND REGIONAL ROAD NETWORK AND MUNICIPAL CENTERS IN SLOVENIA}

\section{Summary}

Presented are the first partial results of the transport-geographical analysis of the former 56 municipal centers in Slovenia. Within the scope of the research study "Geography of Towns" the network was analysed, of roads running to/from 56 municipal centers, with the purpose to discover the regional road network of the above mentioned centers and to learn whether it speaks in favour of nodal structure of central places also from this aspect. Parallel to it, the centers were also analysed from the aspect of traffic flows along the above mentioned main and regional roads. 
In the analysis of transport network of municipal centers, the former 56 municipal centers were taken into consideration, together with their positions in relation to the courses of main and regional roads, that is to say those running directly to/from the municipal centers. Altogether, 243 main and regional roads were analysed, 107 of which were main and 136 were regional roads. It means that on the average, 4.3 roads run to/from each municipal center. Of all municipal centers, the majority of them have 4 main and regional roads; their share amounts to $34.0 \%$. There are $23.2 \%$ of municipal centers with three main roads, and further $23.2 \%$ with five roads. Four or less than four main and regional roads run to/from 35 centers, which is almost two thirds $(65.5 \%)$ of all; to/from the remaining 21 centers, five or more main and regional roads run. This fact speaks in favour of the grid square structure of main and regional roads, and not in favour of Christaller's hexagonal theory on central places.

Basic traits of the relation between the structure of road network of municipal centers and their population number could be summed up into the following general statements:

- In 21 municipal centers with the "hexagonal network" of main and regional roads (municipal centers with five or more than five main and regional roads), 608,262 residents lived in 1991 , or $72.1 \%$ of all residents of municipal centers;

- In 35 municipal centers with four or less than four main and regional roads, 234,908 residents lived in 1991 , which is $27.9 \%$ of all residents in municipal centers.

On more than a half of all counter posts $(59.1 \%$ ), the traffic flow (i.e. the average number of motor vehicles per day) in 1992 amounted to 1000-5000 motor vehicles. There were $19.1 \%$ of counter posts with the average traffic between 5001 and 10,000 motor vehicles, and $11.4 \%$ of counter posts with over 10,000 motor vehicles. Municipal centers with more than 10,000 motor vehicles per day in the network of main and regional roads in 1992 were as follows: Celje, Domžale, Grosuplje, Izola, Koper, Ljubljana, Maribor, Piran, Radovljica, and Žalec. The traffic flow was lower than 1000 motor vehicles only in $10 \%$ of all counter posts. Thus, the traffic flow on main and regional roads leading into/out of the municipal centers amounted on the average to 5200 motor vehicles in 1992 . 